\title{
Teknologi Hijau: Perancangan Mesin Bor Biopori
}

\author{
I Gusti Ngurah Nitya Santhiarsa ${ }^{1}{ }^{*}$ \\ 1) Jurusan Teknik Mesin Universitas Udayana, Kampus Bukit Jimbaran Bali \\ naskah masuk 02/08/2018; diterima 17/10/ 2018; terbit 29/10/2018 \\ doi: 10.24843/JEM.2018.v11.i02.p04
}

\begin{abstract}
Abstrak
Pembangunan fisik di perkotaan berdampak pada dua sisi, pada satu sisi, sarana prasarana untuk pelayanan penduduk semakin lengkap, dan pada sisi lain, terjadi penyusutan areal terbuka hijau. Salah satu akibat susulan dari penyusutan luas ruang terbuka hijau adalah makin menipisnya cadangan air pada cekungan air tanah. Salah satu solusi untuk mengatasi masalah ini adalah dengan pembuatan biopori pada kawasan yang terbangun. Pembuatan biopori bisa dilakukan secara manual yaitu dengan bor biopori manual dan dengan bantuan mesin bor biopori. Proses perancangan mesin bor biopori berdasarkan proses desain elemen mesin, mulai dari analisis karakter kekuatan tanah, analisis gaya dan daya bor, perhitungan elemen mesin yang digunakan, dan pembuatan prototype. Kegiatan perancangan mesin bor biopori telah menghasilkan sebuah prototype mesin dengan daya motor $0,6 \mathrm{~kW}$ dan putaran mesin $500 \mathrm{rpm}$.
\end{abstract}

Kata kunci: Pengukuran aliran, orifice meter, beda tekanan

\begin{abstract}
Physical development on campus on two sides, on the one hand, facilities for population services are increasingly complete, and on the other hand, there is a shrinking of green open areas. One consequence of the subsequent shrinkage of the wide open space is to deplete the air reserve in the ground air basin. One solution to solve this problem is to make a biopori in the area that is built. Biopori production can be done manually, with a manual biopori drill and with the help of a biopori drilling machine. Soil Surface Control Techniques, Characteristic Analysis, Style Analysis, Style Analysis, Energy Style, and Prototype Making. The design of the biopori drilling machine has produced a prototype engine with a motor power of $0.6 \mathrm{~kW}$ and a 500 rpm engine speed.
\end{abstract}

Keywords: Measurement of flow, orifice meter, pressure difference

\section{Pendahuluan}

Mesin bor biopori tanah adalah mesin pembuat lubang tanah atau mesin untuk membuat lubang biopori penyerapan air, menanam pohon, membuat lubang untuk pondasi pagar dan sebagainya. Mesin bor tanah ini memiliki berbagai macam model dan diameter mata bor yang berbeda-beda yang disesuaikan untuk kebutuhan pemakai mulai dari mata bor berdiameter $10 \mathrm{~cm}, 15 \mathrm{~cm}, 20 \mathrm{~cm}$, dan $30 \mathrm{~cm}$, dimana mesin bor tanah ini mampu membuat lubang tanah sampai dengan kedalaman $75 \mathrm{~cm}$ dari permukaan tanah. Mesin bor ini dapat meringankan pekerjaan manusia dalam membuat lubang tanah untuk biopori serta menghasilkan lubang tanah dengan jumlah yang banyak dalam waktu singkat. Mesin bor biopori ini cukup ringan sehingga mudah dibawa kemana-mana pada waktu proses pengoperasiannya. Mesin bor biopori dibutuhkan untuk memudahkan pekerjaan pembuatan lubang biopori oleh masyarakat terutama di daerah perkotaan dimana cukup luas permukaan tanah yang terbangun dan ditutupi oleh beton dan aspal yang kedap air. Permukaan tanah yang tertutup lapisan kedap air akan menghalangi masuknya air hujan ke dalam tanah, hal ini bisa mengakibatkan mudahnya terjadi banjir di kawasan itu, banyak air hujan yang terbuang ke saluran drainase, dan makin menipisnya cadangan air tanah. Kejadian seperti ini tentunya harus dihindari dan diatasi, salah satu cara yang mudah dan efektif adalah dengan program pembuatan lubang biopori. Lubang biopori pada permukaan tanah dapat dibuat dengan alat bor biopori manual atau dengan cara yang lebih cepat, dengan menggunakan mesin bor biopori. Perancangan mesin bor biopori dimulai dengan proses analisis karakter kekuatan tanah, dilanjutkan dengan analisis gaya dan daya bor, kemudian perhitungan elemen mesin yang digunakan, dan akhirnya pembuatan prototype. Berdasarkan uraian di atas, maka perumusan masalah dalam pembuatan perencanaan mesin bor biopori ini adalah bagaimana mekanisme kerja mesin bor biopori, berapa besar power yang dibutuhkan oleh mesin bor biopori dan bahan apa saja yang digunakan untuk membuat mesin bor biopori.

\section{Teori Dasar}

Mesin bor adalah suatu jenis mesin pemotong dimana gerakan utamanya berupa putaran dan arah pemakanan mata bor searah sumbu mesin tersebut, dan proses pengeboran adalah operasi untuk menghasilkan lubang berbentuk bulat dalam permukaan-kerja dengan menggunakan pemotong berputar yang disebut bor dan memiliki fungsi untuk membuat lubang, Bagian utama suatu mesin bor adalah motor penggerak, pencekam bor dan mata bor. Cekam bor atau kopling digunakan untuk memegang mata bor bertangkai silindris, biasanya cekam ini mempunyai 2 atau 3 rahang penjepit, dimana ukuran cekam bor ditentukan oleh diameter terbesar dari mata bor yang dapat dijepit. Mata Bor yang biasa digunakan adalah mata bor spiral, disebut mata bor spiral karena 
mata bor ini mempunyai alur potong melingkar yang berbentuk spiral sepanjang badan, dimana alur spiral mempunyai sudut tatal dan dapat mempercepat keluarnya gemburan tanah selama pengeboran. Mata bor spiral dibuat dari bahan baja karbon, baja campuran, baja kecepatan tinggi dan karbida. Mesin bor biopori mengikuti bentuk dan bagian seperti yang disebutkan di atas, yang berbeda adalah ukuran dan jenis bahan dari mata bor.

\section{Metode Penelitian}

Perancangan prototype mesin bor biopori berdasarkan proses desain elemen mesin, mulai dari analisis karakter kekuatan tanah, analisis gaya dan daya bor, perhitungan elemen mesin yang digunakan ( dalam hal ini hanya dibahas diameter poros dan jenis bahan poros), dan pembuatan prototype. Proses perancangan dan produksi prototype mesin bor biopori dilakukan di Laboratorium Produksi PS Teknik Mesin Fakultas Teknik Universitas Udayana, Bukit Jimbaran.

\section{Hasil dan Pembahasan}

\subsection{Analisis karakter kekuatan tanah}

Tanah grumusol adalah jenis tanah yang terbentuk dari batuan induk kapur dan tuffa vulkanik yang umumnya bersifat basa, miskin hara dan unsur organik lainnya. Sifat kapur itu sendiri yang dapat menyerap semua unsur hara di tanah sehingga kadar kapur yang tinggi dapat menjadi racun bagi tumbuhan.

Jenis tanah ini dipilih dalam perhitungan, karena mempunyai kekuatan geser yang tinggi, yaitu $19,7 \frac{\mathrm{N}}{\mathrm{cm}^{2}}$ $\left(\tau_{\text {tanah }}\right)$ [indonesiatanahsubur.blogspot.com]

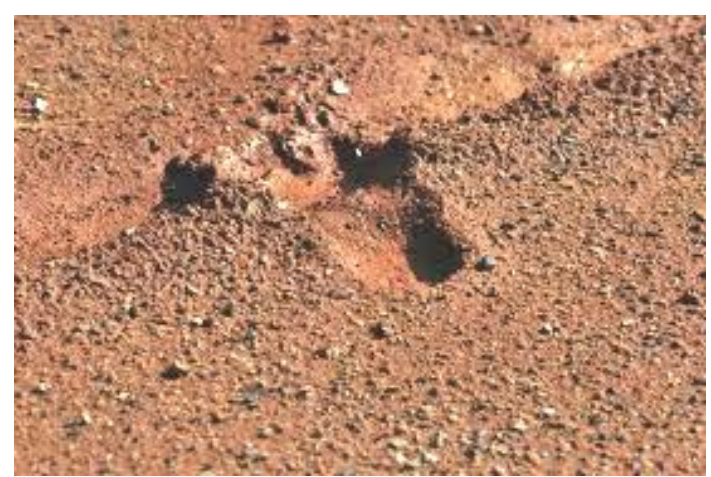

Gambar 1. Tanah Grumusol (sumber: ilmugeografi.com)

Perhitungan Gaya Bor dan Daya Motor

Diketahui : Sudut sudut utama pada mata bor $\eta=20^{\circ}-30^{\circ}$

$\mathrm{Y}=20^{\circ}-35^{\circ}$

$\phi=20^{\circ}-40^{\circ}$

$K_{r}=90^{\circ}$

Perhitungan gaya bor total, akumulasi dari gaya potong ( $\mathrm{Fv}$ ) dan gaya gesek $\left(F_{\alpha}\right)$

$F_{t}=F_{v}+F_{\alpha} \quad(N)$ ( sumber Rochim, 1993) dengan

$$
\begin{aligned}
F_{V} & =\tau_{\text {tanah }} \times \frac{d-d 1}{2} \times \frac{f}{2} \times \frac{\cos \left(\mathrm{n}-\gamma_{0}\right)}{\sin \phi \cdot \cos \left(\phi+\eta+\gamma_{0}\right)} \\
& =19,7 \times 10^{4} \times \frac{0.1-0,01}{2} \times \frac{0,015}{2} \times \frac{\cos \left(30^{0}-20^{0}\right)}{\sin 40^{0} \cdot \cos \left(40^{0}+30^{0}+20^{0}\right)} \\
& =19,7 \times 10^{4} \times 0.045 \times 0.0075 \times \frac{0,98}{0,64 \times 0,64} \\
& =19,7 \times 10^{4} \times 0.045 \times 0.0075 \times 2,39 \\
& =0,015 \times 10^{4}=150 \mathrm{~N}
\end{aligned}
$$

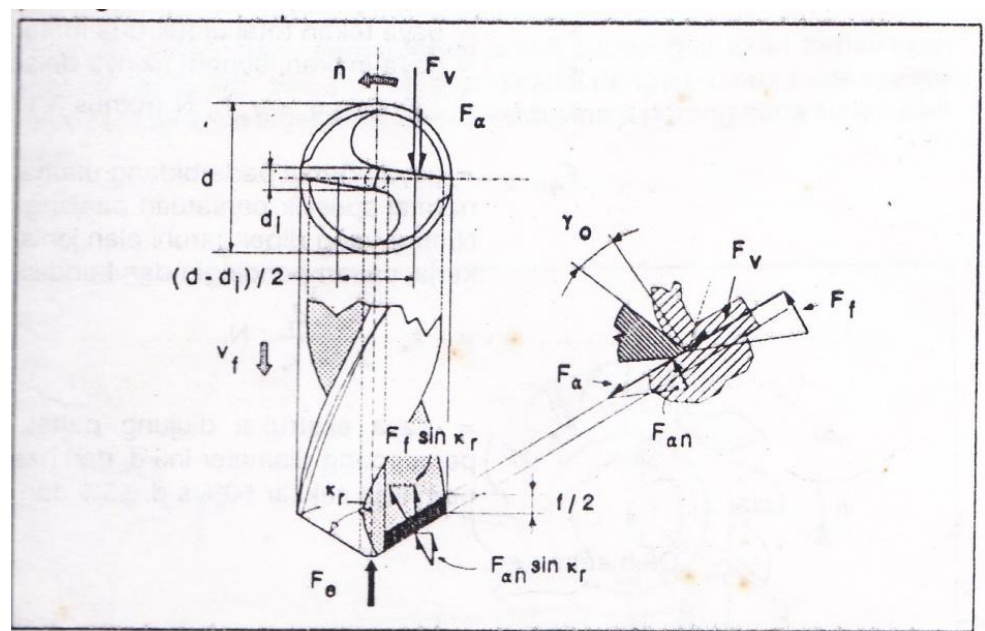

Gambar 2. Gaya Pemotongan pada Proses Bor (sumber Rochim, 1993) 
$F_{\alpha}=k_{f} \times \frac{d-d 1}{2 \sin k_{r}}$

$k_{f}=\frac{\mu \cdot N}{l}=\frac{0,3 \cdot m \cdot g}{l}=\frac{0,3 \cdot 10 \cdot 10}{0,16}=187,5$

$F_{\alpha}=187,5 \times \frac{0,1-0,01}{2 \sin 90^{\circ}}=187,5 \times 0,045=8,4375 \mathrm{~N}$

$F_{t}=F_{v}+F_{\alpha}=150+8,4375=158,4375=160 \mathrm{~N}$

Perhitungan daya bor $(N t)$

$N t=F t \times \vee$ (watt)

$V=$ kecepatan linier poros $=\frac{\pi, d, n}{60}=\frac{3.14,0,1,500}{60}=2,6 \mathrm{~m} / \mathrm{dt}$

$\omega=$ kecepatan sudut poros $=\frac{v}{R}=2,6 / 0.05=52 \mathrm{rad} / \mathrm{dt}$

Jadi daya bor $N t=160 \times 2,6=416$ watt

Percepatan pada poros $(\alpha)$, asumsi waktu yang dibutuhkan sampai putaran maks adalah 10 detik $\alpha=\frac{\Delta w}{\Delta t}=\frac{500-0}{10}=50 \mathrm{rad} / \mathrm{dt}^{2}$

Perhitungan inersia poros $(\mathrm{I})=\mathrm{m}$ poros. $\mathrm{R}^{2}=$ 10. $(0,05)^{2}=0,025$

Perhitungan daya gerak putar bor $(\mathrm{N} \mathrm{s})$

$N_{s}=I . \propto . \omega=0,025 \cdot 50.52=65$ watt

Sehingga daya kerja seluruhnya

$N_{\text {Tot }}=N_{t}+N_{s}=416+65=481$ watt $===500$ watt

Dengan estimasi efisiensi motor $(\tilde{\eta})=0,95$, maka daya motor total

$N_{m}=\frac{N_{\text {Tot }}}{\bar{\eta}}=\frac{500}{0,95}=526$ watt, diambil 600 watt

\subsection{Penentuan diameter poros mata bor dengan analisis beban Buckling( beban tekuk)}

Beban yang terjadi pada poros (w), pada poros terdapat beban dari berat motor $\left(w_{\text {motor }}\right.$ ) dengan arah dari atas, dan beban dari reaksi tanah ( $w_{\text {tanah }}$ ) dari arah bawah, maka besar beban tekuk pada poros adalah selisih dari keduanya

$$
\begin{aligned}
& w_{\text {tekan }}=w_{\text {motor }}-w_{\text {tanah }} \\
& w_{\text {motor }}=m \text { motor } \cdot g=10 \cdot 10 \frac{m}{d t 2}=100 \mathrm{~N} \\
& w_{\text {tanah }}: \\
& F=\tau_{\text {tanah }} A=19,7 \times 10^{4} \times\left[\frac{3,14 \times(0,1)^{2}}{4}\right]=1546,45 \mathrm{~N} \\
& -\left[w_{\text {motor }}+w_{\text {tekan }}\right]+\left[w_{\text {tanah }}\right]=0 \\
& -[100 \mathrm{~N}]-w_{\text {tekan }}+1546,45=0 \\
& w_{\text {tekan }}=1546,45-100=1446,45 \mathrm{~N} \quad \text { hal ini } \\
& \text { Dalam } \\
& w_{\text {tekan }}=\text { Pcr }=\text { beban kritis }=1446,45 \mathrm{~N}
\end{aligned}
$$

Mencari diameter poros bila mesin sedang berkerja tidak terjadi buckling, kondisi jepit-jepit

$y=e\left[\tan \left(\frac{1}{2} \sqrt{\frac{P}{E I}}\right) \sin \left(\sqrt{\frac{P}{E I}} x\right)+\cos \left(\sqrt{\frac{P}{E I} x}\right)-1\right]$

( sumber Khurmi, 2004)

$$
\begin{aligned}
& \delta=e\left[\sec \left(\sqrt{\frac{P}{E I}} \frac{1}{2}\right)-1\right] \\
& M_{\max }=P(e+\delta)=P e \sec \left(\frac{1}{2} \sqrt{\frac{P}{E I}}\right) \\
& \delta=e\left[\sec \left(\sqrt{\frac{P}{E I} \frac{1}{2}}\right)-1\right] \\
& \delta=10\left[\sec \left(\sqrt{\frac{1446,45}{6,14 \times 981,2}} \frac{1}{2}\right)-1\right] \\
& \delta=10\left[\sec \left(\sqrt{0,024} \frac{1}{2}\right)-1\right] \\
& \delta=10[\sec (0,155 \times 0,5)-1] \\
& \delta=10[\sec (-0,345)-1] \\
& \delta=10\left[\frac{1}{\cos (-0,345)}\right] \\
& \delta=10[1,01-1] \\
& \delta=10[0,01] \\
& \delta=0,1
\end{aligned}
$$

Jadi untuk mencari nilai Momen Tekuk $M_{\max }$ :

$M_{\max }=P(e+\delta)=1446,45(5+0,1)=7376,895$

Besar Momen torsi yang terjadi :

$T=9,74 \times 10^{5} \times \frac{0,6}{500}=1168,8 \frac{\mathrm{kg}}{\mathrm{mm}^{2}}$

Menghitung $\tau_{\alpha}$ (tegangan geser ijin ) menggunakan baja khrom nikel (JIS G 4102) SNC22 dengan kekuatan tarik $100 \frac{\mathrm{kg}}{\mathrm{mm}^{2}}$ ( sumber Sularso, 2000) $\tau_{\alpha}=\frac{\tau_{\beta}}{S f_{1} S f_{2}}=\frac{100}{6 \times 2}=8,3 \frac{\mathrm{kg}}{\mathrm{mm}^{2}} \times 9,81 \frac{\mathrm{m}}{\mathrm{g}^{2}}=81,423 \mathrm{~kg} / \mathrm{mm} 2$

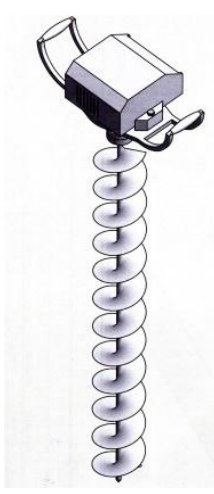

Gambar 3 . Gambar Rancangan 3-D Mesin Bor Biopori

Perhitungan diameter poros mata bor $(d s)$ $d_{s} \geq\left[\left(\frac{5,1}{\tau_{\alpha}}\right) \sqrt{\left(k_{m} M\right)^{2}}+\left(k_{t} \cdot T\right)^{2}\right]^{\frac{1}{3}}$ 


$$
\begin{aligned}
& d_{s} \geq\left[\left(\frac{5,1}{81,423}\right) \sqrt{(2 \times 7376,895)^{2}}+(1,5 \times 1168,8)^{2}\right]^{\frac{1}{3}} \\
& d_{s} \geq\left[0,06(14857,59)^{\frac{1}{3}}\right. \\
& d_{s} \geq \sqrt[3]{891,455}
\end{aligned}
$$

$d_{s} \geq 9,5 \mathrm{~mm}$, sehingga diameter poros mata bor dipilih adalah $10 \mathrm{~mm}$.

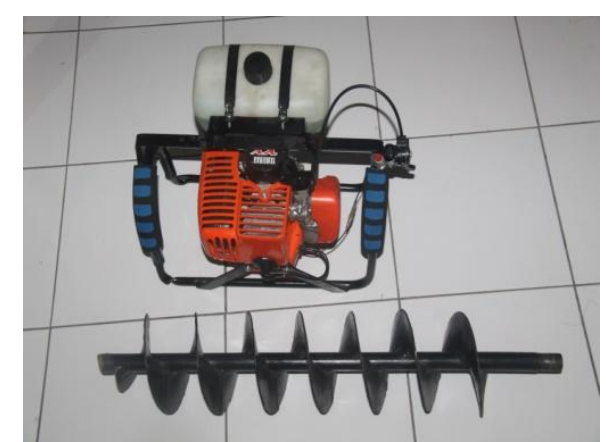

Gambar 4. Prototype Mesin Bor Biopori

\section{Simpulan}

Perancangan prototype mesin bor biopori telah dapat dilakukan dengan hasil sebagai berikut: diameter poros $10 \mathrm{~mm}$ dengan bahan baja khrom nikel (JIS G 4102) SNC22, mata bor dengan ukuran diameter $100 \mathrm{~mm}$, dengan bahan baja khrom nikel (JIS G 4102) SNC22 , serta motor penggerak dengan daya $0,6 \mathrm{KW}$ dan putaran $500 \mathrm{rpm}$.

\section{Ucapan Terima Kasih}

Perancangan prototype mesin bor biopori dapat terlaksana dengan baik karena dukungan dan bantuan dari I Gede Indra Wiguna, I Made Arya Mahardika, dan Dwi Wahyu Krisna Yoga, terutama dalam proses pembuatan prototype, untuk itu diucapkan terima kasih.

\section{Daftar Pustaka}

[1] Rochim, Taufiq, 1993, Teori dan Teknologi, Proses Pemesinan, Higher Education Development Support Project, Jakarta

[2] Sularso, 2000, Dasar Dasar Perencanaan dan Pemilihan Elemen Mesin, PT Pradnya Paramita, Jakarta

[3] Khurmi, RS,JK Gupta,,2004, A Text Book of Machine Design, SI Units, Eurasia Publishing House, Ltd, New Delhi 